\begin{tabular}{|c|c|}
\hline Title & Significance of $\mathrm{Mn}$ and Fe for growth of coastal marine diatom Thal assiosira weissflogii \\
\hline Author(s) & Ushizaka, Satomi; Sugie, Kohji; Y amada, Masumi; Kasahara, Mariko; Kuma, Kenshi \\
\hline Citation & $\begin{array}{l}\text { Fisheries science, 74(5), 1137-1145 } \\
\text { https://doi.org/10.1111/j.1444 2906.2008.01633.x }\end{array}$ \\
\hline Issue Date & 200809 \\
\hline DOC URL & http:/hdl.handle.net/2115/53364 \\
\hline Rights & ○ 2008 公益社団法人日本水産学会; @ 2008The Japanese Society of Fisheries Science \\
\hline Type & article \\
\hline File Information & FS74_1137.pdf \\
\hline
\end{tabular}

Instructions for use 


\title{
Significance of Mn and Fe for growth of coastal marine diatom Thalassiosira weissflogii
}

\author{
Satomi USHIZAKA, ${ }^{1}$ Kohji SUGIE, ${ }^{1}$ Masumi YAMADA, ${ }^{1}$ Mariko KASAHARA ${ }^{2}$ AND \\ KENSHI KUMA ${ }^{1,2 *}$
${ }^{1}$ Graduate School of Environmental Science, Hokkaido University, Sapporo, Hokkaido 060-0810, and ${ }^{2}$ Faculty of Fisheries Sciences, Hokkaido University, Hakodate, Hokkaido 041-8611, Japan

\begin{abstract}
The significance of $\mathrm{Mn}$ and $\mathrm{Fe}$ for the growth of a coastal marine diatom Thalassiosira weissflogii was investigated by performing culture experiments containing macronutrients with either $\mathrm{Mn}$ or $\mathrm{Fe}$, or both. Only the addition of both $\mathrm{Mn}$ and $\mathrm{Fe}$ induced the highest growth rates and maximal cell yields. Maximal growth was maintained in continuous culture media, which were repeatedly prepared by an inoculation of pre-culture and the addition of both $\mathrm{Mn}$ and $\mathrm{Fe}$ to the control culture medium containing macronutrients. In particular, it was found that the full growth recovery in $\mathrm{Mn}$-sufficient medium (without added $\mathrm{Fe}$ ) is accomplished by the addition of Fe even after several days' incubation. On the contrary, there was no sufficient growth recovery by the addition of Mn after a long incubation time in Fe-sufficient medium but without additional $\mathrm{Mn}$. These results suggest that T. weissflogii in Mn-sufficient waters retains the ability for full physiological recovery for a long time, probably resulting from the decrease in the oxidative stress of phytoplankton by the production of antioxidant enzyme Mn superoxide dismutase during a long incubation period.
\end{abstract}

KEY WORDS: coastal marine diatom, iron, manganese, maximal cell yields, specific growth rate, Thalassiosira weissflogii.

\section{INTRODUCTION}

Iron is an essential micronutrient for phytoplankton growth, as it is an important component of such biochemical processes as photosynthetic and respiratory electron transport, nitrate and nitrite reduction, chlorophyll synthesis and other biosynthetic or degradative reactions. ${ }^{1,2}$ However, iron in oxic sea water is in the thermodynamically stable $3+$ oxidation state and presents predominantly in insoluble particulate form. ${ }^{3,4}$ Therefore, iron supply is thought to regulate primary production in coastal and oceanic regions where the surface waters are deficient in iron. Manganese is also essential to all organisms and has particular importance in plant nutrition. In general, manganese is required for oxidation of water in photosynthesis and for detoxification of superoxide radicals. ${ }^{5}$ Manganese in sea water occurs dissolved in the $2+$ oxidation state. Observed concentrations for dissolved $\mathrm{Mn}$ in open ocean waters are

*Corresponding author: Tel: 81-11-706-2324.

Fax: 81-11-706-2324. Email: kuma@fish.hokudai.ac.jp

Received 7 September 2007. Accepted 21 March 2008. normally $0.1-3$ nM. ${ }^{6-9}$ These higher concentrations than the equilibrium concentration of dissolved $\mathrm{Mn}$ with solid $\mathrm{Mn}^{\mathrm{IV}} \mathrm{O}_{2}$ or $\mathrm{Mn}^{\mathrm{III}} \mathrm{OOH}$ are partially maintained by the relatively slow oxidation kinetics of $\mathrm{Mn}^{2+}$ and by photochemical reduction processes and photoinhibition of microbial oxidation of $\mathrm{Mn}^{2+}$ in oceanic surface waters. ${ }^{10,11}$ Typical dissolved Mn vertical profiles in the open ocean show surface dissolved Mn maxima of approximately $1 \mathrm{nM}$, evidence of atmospheric input to the surface layer. ${ }^{8,9,12}$ Therefore, manganese could potentially limit oceanic productivity in remote oceanic regimes with high nutrients and low atmospheric input without an adequate external supply from the atmosphere or from horizontal mixing and phytoplankton growth in culture experiments. ${ }^{13,14}$ Conversely, some trace metals have been shown to be toxic to organisms at very low concentrations. Therefore, trace metals can have either a positive or negative effect on phytoplankton growth in culture media and in the oceans.

In the present study, it has been found that sufficient phytoplankton growth is not accomplished in continuous cultivations by the addition of only $\mathrm{Fe}$ and macronutrients $\left(\mathrm{NO}_{3}{ }^{-}, \mathrm{PO}_{4}{ }^{3-}\right.$ and $\left.\mathrm{SiO}_{2}\right)$. 
Therefore, the effects of especially $\mathrm{Mn}$ in addition to other trace metals such as $\mathrm{Co}, \mathrm{Ni}, \mathrm{Cu}$ and $\mathrm{Zn}$ on the growth of a coastal marine diatom Thalassiosira weissflogii, which has been investigated in many studies for the rates of growth and trace metal uptake, were examined by the addition of these trace metals in culture media in the presence of Fe and macronutrients.

\section{MATERIALS AND METHODS}

\section{Chemical analysis for natural sea water}

Sea water was collected from a coastal region near Hokkaido, Japan, northern Sea of Japan (salinity $=33.8$ ) and was filtered through an acid-cleaned $0.22-\mu \mathrm{m}$ cellulose membrane filter (Millipore, Billerica, MA, USA). The 100-mL filtrate for Fe concentration analysis was buffered at $\mathrm{pH} 3.2$ with a $10 \mathrm{M}$ formic acid-2.4 M ammonium formate buffer solution ( $0.5 \mathrm{~mL}$ per $100 \mathrm{~mL}$ filtrate). The Fe concentration in buffered filtrate was determined by an automated Fe analyzer (Kimoto Electric, Osaka, Japan) by use of a combination of concentration onto an 8-hydroxyquinoline chelating column and luminal-hydrogen peroxide chemiluminescence detection in a closed flow-through system. ${ }^{15,16}$ The Fe concentration was approximately $2 \mathrm{nM}$. The concentrations of $\mathrm{NO}_{3}^{-}+\mathrm{NO}_{2}^{-}, \mathrm{PO}_{4}^{3-}$, and $\mathrm{SiO}_{2}$ in the filtered sea water measured by an autoanalyzer (Technicon, Buffalo Grove, IL, USA) were less than $0.5,0.1$ and $5 \mu \mathrm{M}$, respectively, which are negligible values compared with the concentrations added in the culture experiments. All bottles, flasks and tubes used in our experiments were acid-washed (soaked for at least $24 \mathrm{~h}$ in 1 or $3 \mathrm{M} \mathrm{HCl}$ solution or $1 \mathrm{M} \mathrm{HCl}$ for polycarbonate apparatuses) followed by repetitive washes with Milli-Q water (>18.0 M $\Omega$ / $\mathrm{cm}$, Millipore). All preparation and sampling for experiments was performed in a Class 100 laminar flow cabinet to avoid inadvertent trace metal contamination.

\section{Cullture experiments}

The filtered sea water was autoclaved for $20 \mathrm{~min}$ at $121^{\circ} \mathrm{C}$, and the culture medium was prepared by adding modified f/ 2 nutrient and $\mathrm{f} / 2$ metals $^{17}$ to the autoclaved filtered sea water. The modified $\mathrm{f} / 2$ medium contained $880 \mu \mathrm{M} \mathrm{NO}_{3}{ }^{-}, 38 \mu \mathrm{M} \mathrm{PO}_{4}{ }^{3-}$ and $105 \mu \mathrm{M} \mathrm{SiO}{ }_{2}$ for nutrients and $11.7 \mu \mathrm{M} \mathrm{Fe}^{\mathrm{III}}$, $0.44 \mu \mathrm{M} \mathrm{Co}^{\mathrm{II}}, 0.91 \mu \mathrm{M} \mathrm{Mn}^{\text {II }}, 73 \mathrm{nM} \mathrm{Zn}^{\text {II }}, 28 \mathrm{nM} \mathrm{Cu}{ }^{\text {II }}$ and $29 \mathrm{nM} \mathrm{Mo}{ }^{\mathrm{VI}}$ with $15 \mu \mathrm{M}$ EDTA for metals. The chain-forming coastal marine diatom $T$. weissflogii was grown in $50 \mathrm{~mL}$ of the $\mathrm{f} / 2$ medium in a $100 \mathrm{~mL}$ polycarbonate Erlenmeyer flask. Cells were grown at $20^{\circ} \mathrm{C}$ under $150 \mu \mathrm{mol}$ photons $/ \mathrm{m}^{2}$ per s fluorescent light (12 h:12 h light-dark). An f/2 nutrient stock solution and then a small amount of culture $(\sim 250-500 \mu \mathrm{L})$ in an initial stationary growth phase ( $\geq 100000$ cells $/ \mathrm{mL}$ after 5 days incubation) were added to $50 \mathrm{~mL}$ of the first culture medium [Direct$\mathrm{Fe}^{\mathrm{III}}$ (first)], to which acidic ferric iron stock solution $\left[25 \mu \mathrm{M} \mathrm{Fe}\right.$ iII; $\mathrm{FeNH}_{4}\left(\mathrm{SO}_{4}\right)_{2} \cdot 12 \mathrm{H}_{2} \mathrm{O}$ in $5 \mathrm{mM} \mathrm{HCl}$, $\mathrm{pH}$ 2.3] was added to make an iron concentration of $100 \mathrm{nM}$. The $\mathrm{pH}$ of the sea water after the acidic iron addition was 8.0. All major nutrient stocks were passed through Chelex 100 ion-exchange resin to remove trace metals. ${ }^{18}$ Cells in the Direct$\mathrm{Fe}^{\mathrm{III}}$ (first) medium, to which only macronutrients and $\mathrm{Fe}^{\mathrm{III}}$ was added, were grown to obtain the cell concentration (1000 cells $/ \mathrm{mL}$ ) expected at the start of the following culture experiments. In our previous studies, ${ }^{19-22}$ the effect of direct Fe input was examined by adding a small amount of acidic ferric iron stock solution directly together with an inoculation of culture into the control culture medium, resulting in the highest phytoplankton growth rate and the highest maximal cell yields. In the following culture experiments, all culture media contained $880 \mu \mathrm{M} \mathrm{NO}_{3}{ }^{-}, 38 \mu \mathrm{M} \mathrm{PO}_{4}{ }^{3-}$, and $105 \mu \mathrm{M} \mathrm{SiO}_{2}$ for nutrient. In addition, metals (except for $\mathrm{Mn}$ and/or Fe) and EDTA in the $\mathrm{f} / 2$ metal medium are diluted to extremely low concentrations $(<0.1 \mathrm{nM}$ for each metal and $<1.5 \mathrm{nM}$ for EDTA with low conditional stability constant, $K_{\text {M-EDTA,M }}^{\prime}=[\mathrm{M}-\mathrm{EDTA}] /$ $\left[\mathrm{M}^{\prime}\right]\left[\mathrm{EDTA}^{\prime}\right]$; $\mathrm{M}$, metal) in sea water, negligible values in the following culture experiments ${ }^{19,20}$ ) in the second culture medium with twice inoculations of culture. It has been reported that the concentrations of natural Fe-binding organic ligands in surface sea waters are normally in the low range of $0.3-3.6 \mathrm{nM},{ }^{20}$ which are negligible values compared with the Fe concentration $(100 \mathrm{nM})$ in the culture experiments.

\section{Continuous cultivations by only addition of Fe and macronutrients}

A small amount of culture $(\sim 250-500 \mu \mathrm{L})$ at an initial stationary growth phase in the Direct-Fe $\mathrm{e}^{\mathrm{II}}$ (first) medium was added to the Direct-Fe ${ }^{\text {III }}$ (second) medium, to which only both $\mathrm{Fe}^{\mathrm{III}}$ and nutrient were added, to make the cell concentration of 1000 cells $/ \mathrm{mL}$ at the start of the culture experiment. Continuously, cells at an initial stationary growth phase in the Direct-Fe ${ }^{\mathrm{III}}$ (second) medium was also inoculated to the Direct-Fe ${ }^{\text {III }}$ (third) medium, to which only both $\mathrm{Fe}^{\mathrm{III}}$ and nutrient were added [Table 1 (1)], to make a cell concentration of 1000 cells $/ \mathrm{mL}$ at the start. 
Table 1 Growth rate $(\mu)$ and maximal cell yields (cells $/ \mathrm{mL}$ ) of Thalassiosira weissflogii in $\mathrm{f} / 2$ metal medium, direct trace metals $\left(\mathrm{Mn}^{\mathrm{II}}, \mathrm{Fe}^{\mathrm{III}}, \mathrm{Co}^{\mathrm{II}}, \mathrm{Ni}^{\mathrm{II}}, \mathrm{Cu}^{\mathrm{II}}, \mathrm{Zn}^{\mathrm{II}}\right)$ media with/without the addition of $\mathrm{Fe}^{\mathrm{III}}$ and direct $\mathrm{Fe}^{\mathrm{III}}$ media with $\mathrm{Mn}^{\mathrm{II}}(n=3)$

\begin{tabular}{|c|c|c|c|c|}
\hline Medium & & $\begin{array}{l}\text { Addition of trace metals } \\
\text { (concentration, } n M \text { ) }\end{array}$ & $\begin{array}{c}\text { Specific growth rate } \\
(\mu, / \text { day })\end{array}$ & $\begin{array}{r}\text { Maximal cell yi } \\
\left(\times 10^{3} \text { cells } / \mathrm{m}\right.\end{array}$ \\
\hline \multicolumn{5}{|c|}{ (1) Growth rate experiments in $\mathrm{f} / 2$ metal medium and continuous direct $\mathrm{Fe}^{\mathrm{III}}$ media } \\
\hline $\mathrm{f} / 2$ metal & 0 & $\mathrm{f} / 2$ metals & $0.95-0.98(0-5 \mathrm{~d})$ & $171-208$ \\
\hline $\mathrm{Fe}^{\mathrm{III}}$ & first & $\mathrm{Fe}^{\mathrm{III}}(100 \mathrm{nM})$ & $0.90-0.94(0-5 \mathrm{~d})$ & $157-169$ \\
\hline $\mathrm{Fe}^{\mathrm{III}}$ & second & $\mathrm{Fe}^{\mathrm{III}}(100 \mathrm{nM})$ & $0.58-0.70(0-5 \mathrm{~d})$ & $25-28$ \\
\hline Control & second & no Fe & $0.28-0.41(0-5 \mathrm{~d})$ & $5-6$ \\
\hline $\mathrm{Fe}^{\mathrm{III}}$ & third & $\mathrm{Fe}^{\mathrm{IIII}}(100 \mathrm{nM})$ & $0.20-0.70(0-5 \mathrm{~d})$ & $36-40$ \\
\hline \multicolumn{5}{|c|}{ (2) Growth rate experiments in trace metals media } \\
\hline (a) $\mathrm{Fe}^{\mathrm{III}}$ & second & $\mathrm{Fe}^{\mathrm{III}}(100 \mathrm{nM})$ & $0.66-0.73(0-5 \mathrm{~d})$ & $22-29$ \\
\hline $\mathrm{Mn}$ & second & $\mathrm{Mn}^{\mathrm{II}}(25 \mathrm{nM})$ & $0.65-0.70(0-5 \mathrm{~d})$ & $33-38$ \\
\hline Co & second & $\mathrm{Co}^{\mathrm{II}}(25 \mathrm{nM})$ & $0.64-0.66(0-5 \mathrm{~d})$ & $22-23$ \\
\hline $\mathrm{Ni}$ & second & $\mathrm{Ni}^{\mathrm{II}}(25 \mathrm{nM})$ & $0.64-0.70(0-5 \mathrm{~d})$ & $21-24$ \\
\hline $\mathrm{Cu}$ & second & $\mathrm{Cu}^{\mathrm{II}}(25 \mathrm{nM})$ & $0.62-0.66(0-5 \mathrm{~d})$ & $21-22$ \\
\hline $\mathrm{Zn}$ & second & $\mathrm{Zn}^{\text {II }}(25 \mathrm{nM})$ & $0.63-0.66(0-5 d)$ & $22-23$ \\
\hline (b) $\mathrm{Fe}+\mathrm{Mn}$ & second & $\mathrm{Fe}^{\mathrm{III}}+\mathrm{Mn}^{\mathrm{II}}(100+25 \mathrm{nM})$ & $0.92-0.94(0-5 \mathrm{~d})$ & $140-163$ \\
\hline $\mathrm{Fe}+\mathrm{Co}$ & second & $\mathrm{Fe}^{\mathrm{III}}+\mathrm{Co}^{\mathrm{II}}(100+25 \mathrm{nM})$ & $0.60-0.61(0-5 \mathrm{~d})$ & $23-24$ \\
\hline $\mathrm{Fe}+\mathrm{Ni}$ & second & $\mathrm{Fe}^{\mathrm{III}}+\mathrm{Ni}^{\mathrm{II}}(100+25 \mathrm{nM})$ & $0.58-0.59(0-5 d)$ & $21-23$ \\
\hline $\mathrm{Fe}+\mathrm{Cu}$ & second & $\mathrm{Fe}^{\mathrm{III}}+\mathrm{Cu}^{\mathrm{II}}(100+25 \mathrm{nM})$ & $0.47-0.52(0-5 \mathrm{~d})$ & $13-16$ \\
\hline $\mathrm{Fe}+\mathrm{Zn}$ & second & $\mathrm{Fe}^{\mathrm{III}}+\mathrm{Zn}^{\mathrm{II}}(100+25 \mathrm{nM})$ & $0.60-0.62(0-5 \mathrm{~d})$ & $23-25$ \\
\hline
\end{tabular}

(3) Growth rate experiments in continuous direct $\mathrm{Fe}^{\mathrm{III}}$ media with the addition of $\mathrm{Mn}(25 \mathrm{nM})$ and in direct- $\mathrm{Fe}^{\mathrm{III}}$ (second) media by addition of different

Mn concentrations $(0,1,5,10,25$ and $50 \mathrm{nM})$
(a) $\mathrm{Fe}+\mathrm{Mn}$
$\mathrm{Fe}+\mathrm{Mn}$
first
second
$\mathrm{Fe}^{\mathrm{III}}+\mathrm{Mn}^{\mathrm{II}}(100+25 \mathrm{nM})$
$\mathrm{Fe}^{\mathrm{III}}+\mathrm{Mn}^{\mathrm{II}}(100+25 \mathrm{nM})$
0.92-0.95 (0-5 d)
$0.94-1.00(0-5 \mathrm{~d})$
146-154
$\mathrm{Fe}+\mathrm{Mn} \quad$ third
$\mathrm{Fe}^{\mathrm{III}}+\mathrm{Mn}^{\mathrm{II}}(100+25 \mathrm{nM})$
0.90-0.93 (0-5 d)
133-159
$\mathrm{Fe}+\mathrm{Mn}$
fifth
$\mathrm{Fe}^{\mathrm{III}}+\mathrm{Mn}^{\mathrm{II}}(100+25 \mathrm{nM})$
$0.93-0.98(0-5 \mathrm{~d})$
$\mathrm{Fe}^{\mathrm{IIII}}$. (100 nM)
$0.59-0.63(0-4 \mathrm{~d})$
$\mathrm{Fe}+\mathrm{Mn}$
second
$\mathrm{Fe}^{\mathrm{III}}+\mathrm{Mn}^{\mathrm{II}}(100+1 \mathrm{nM})$
$\mathrm{Fe}+\mathrm{Mn}$
second
$\mathrm{Fe}^{\mathrm{III}}+\mathrm{Mn}^{\mathrm{II}}(100+5 \mathrm{nM})$
$0.69-0.71(0-5 \mathrm{~d})$
$132-163$
$\mathrm{Fe}+\mathrm{Mn}$
second
$0.92-0.94(0-5 \mathrm{~d})$
146-163
$\mathrm{Fe}^{\mathrm{III}}+\mathrm{Mn}^{\mathrm{II}}(100+10 \mathrm{nM})$
$\begin{array}{ll}\text { second } & \mathrm{Fe}^{\mathrm{III}}+\mathrm{Mn}^{\mathrm{II}}(100+25 \mathrm{nM}) \\ \text { second } & \mathrm{Fe}^{\mathrm{III}}+\mathrm{Mn}^{\mathrm{II}}(100+50 \mathrm{nM})\end{array}$
$0.89-0.90(0-5 \mathrm{~d})$
$0.90-0.93(0-5 \mathrm{~d})$
$0.88-0.89(0-5 \mathrm{~d})$
$10-11$
40-43
161-171
167-171
164-166
Fe+Mn
second

(4) Growth rate experiments in Direct Fe $\mathrm{FI}^{\mathrm{III}}$ (second) media by different timing of Mn addition (25 $\mathrm{nM}$ ) or Fe+Mn addition $(100 \mathrm{nM}+25 \mathrm{nM})$ and Direct

Mn (25 nM) media by different timing of Fe addition (100 nM)
(a) $\mathrm{Fe}+\mathrm{Mn}$
$\mathrm{Fe}+\mathrm{Mn}$
second $(0 \mathrm{~d})$
$\mathrm{Fe}^{\mathrm{III}}+\mathrm{Mn}^{\mathrm{II}}(100+25 \mathrm{nM})$
second $(4 \mathrm{~d})$
$\mathrm{Fe}+\mathrm{Mn}$
$\mathrm{Fe} \times 2+\mathrm{Mn}$
$\mathrm{Fe}+\mathrm{Mn}$
$\mathrm{Fe} \times 2+\mathrm{Mn}$
second $(6 \mathrm{~d})$
$\mathrm{Fe}^{\mathrm{III}}+\mathrm{Mn}^{\mathrm{II}}(100+25 \mathrm{nM})$
$0.95-0.97(0-5 \mathrm{~d})$
$0.67-0.76(4-6 \mathrm{~d})$
$\mathrm{Fe}^{\mathrm{III}}+\mathrm{Mn}^{\mathrm{II}}(100+25 \mathrm{nM})$
second $(8 \mathrm{~d})$
$\mathrm{Fe}^{\mathrm{III}} \times 2+\mathrm{Mn}^{\mathrm{II}}(100 \times 2+25 \mathrm{nM})$
$0.40-0.57(6-8 \mathrm{~d})$
140-171
$\mathrm{Fe}^{\mathrm{III}}+\mathrm{Mn}^{\mathrm{II}}(100+25 \mathrm{nM})$
second $(8 \mathrm{~d})$
$\mathrm{Fe}^{\mathrm{III}} \times 2+\mathrm{Mn}^{\mathrm{II}}(100 \times 2+25 \mathrm{nM})$
$0.23-0.57(6-8 \mathrm{~d})$
ND (8-9 d)
ND (8-9 d)
$\mathrm{Mn}^{\mathrm{II}}+\mathrm{Fe}^{\mathrm{III}}(25+100 \mathrm{nM})$
$\mathrm{Mn}+\mathrm{Fe}$
$\mathrm{Mn}+\mathrm{Fe}$
second $(0 \mathrm{~d})$
second $(2 \mathrm{~d})$
$\mathrm{Mn}^{\mathrm{II}}+\mathrm{Fe}^{\mathrm{III}}(25+100 \mathrm{nM})$
second $(4 \mathrm{~d})$
$\mathrm{Mn}^{\mathrm{II}}+\mathrm{Fe}^{\mathrm{III}}(25+100 \mathrm{nM})$
second $(6 \mathrm{~d})$
$\mathrm{Mn}^{\mathrm{II}}+\mathrm{Fe}^{\mathrm{III}}(25+100 \mathrm{nM})$
second ( $8 \mathrm{~d}$ )
$\mathrm{Mn}^{\mathrm{II}}+\mathrm{Fe}^{\mathrm{III}}(25+100 \mathrm{nM})$
$1.00-1.05(0-5 \mathrm{~d})$
$0.79-0.84(2-6 \mathrm{~d})$
$0.66-0.68$ (4-8 d)
$0.56-0.62(6-10 \mathrm{~d})$
0.68-0.69 (8-11 d)
156-169
70-83
66-79
20-22
$17-22$
139-170
148-173
154-161
146-159
146-149

ND, Not determined.

\section{Effect of other trace metals in second culture media}

The effect of trace metals such as $\mathrm{Mn}^{\mathrm{II}}, \mathrm{Co}^{\mathrm{II}}, \mathrm{Ni}^{\mathrm{II}}$, $\mathrm{Cu}^{\mathrm{II}}$ and $\mathrm{Zn}^{\text {II }}$ (metal chloride or sulfate) on the growth of T. weissflogii was examined for culture media with and without the addition of $\mathrm{Fe}^{\mathrm{III}}$
[Table 1 (2)]. A small amount of culture at an initial stationary growth phase in the Direct-Fe ${ }^{\text {III }}$ (first) medium was added to the Direct-Metal (second) medium without any added $\mathrm{Fe}^{\mathrm{III}}$ and Direct$\mathrm{Fe}+$ Metal (second) medium with $\mathrm{Fe}^{\mathrm{III}}$ to which only both nutrient and one of the trace metals were added. Just after an inoculation of culture into the 
control culture medium containing nutrient, iron and/or one of other trace metals were directly added to make concentrations of $100 \mathrm{nM}$ for $\mathrm{Fe}^{\mathrm{III}}$ and $25 \mathrm{nM}$ for each other trace metal.

\section{Continuous cultivations by addition of $\mathrm{Fe}, \mathrm{Mn}$ and macronutrients}

An inoculation of culture in the $\mathrm{f} / 2$ metal medium to the control culture medium containing nutrient was followed by the addition of both $\mathrm{Fe}^{\mathrm{III}}$ and $\mathrm{Mn}^{\mathrm{II}}$ as Direct-Fe $+\mathrm{Mn}$ (first) medium. Repeatedly, that in the Direct-Fe $+\mathrm{Mn}$ (first) medium was also added to the second culture medium with only the addition of both $\mathrm{Fe}^{\mathrm{III}}$ and $\mathrm{Mn}^{\mathrm{II}}$ as Direct-Fe $+\mathrm{Mn}$ (second) medium. Similarly, the third, fourth and fifth [Direct-Fe $+\mathrm{Mn}$ (third, fourth and fifth)] culture media were also prepared by an inoculation of pre-culture and the addition of both $\mathrm{Fe}^{\mathrm{III}}$ and $\mathrm{Mn}^{\mathrm{II}}$ to the control culture medium [Table 1 (3a)]. The final concentrations of $\mathrm{Fe}^{\mathrm{III}}$ and $\mathrm{Mn}^{\mathrm{II}}$ in each culture medium are 100 and $25 \mathrm{nM}$, respectively: In addition, the effect of $\mathrm{Mn}^{\mathrm{II}}$ concentrations on the growth of T. weissflogii was examined in the Direct-Fe $+\mathrm{Mn}$ (second) medium with concentrations of $1,5,10,25$ and $50 \mathrm{nM} \mathrm{Mn}^{\mathrm{II}}$ and of $100 \mathrm{nM} \mathrm{Fe} \mathrm{III}^{\mathrm{III}}$ [Table 1 (3b)].

\section{Effect of Mn and/or Fe addition with different timing}

The effect of direct $\mathrm{Mn}$ input to the Direct-Fe ${ }^{\mathrm{III}}$ (second) medium with different timing on the growth of $T$. weissflogii was examined by the addition of $\mathrm{Mn}^{\mathrm{II}}$ after $0,4,6$ and 8 days incubation and by the addition of both $\mathrm{Fe}^{\mathrm{III}}$ and $\mathrm{Mn}^{\mathrm{II}}$ after 6 and 8 days incubation in the Direct-Fe ${ }^{\text {III }}$ (second) medium. In addition, the effect of direct Fe input to the Direct-Mn (second) medium was carried out by the addition of $\mathrm{Fe}^{\mathrm{III}}$ after $0,2,4,6$ and 8 days incubation in the Direct-Mn (second) medium [Table 1 (4)]. The final concentrations of $\mathrm{Mn}^{\mathrm{II}}$ and $\mathrm{Fe}^{\mathrm{III}}$ in each culture medium are 25 and $100 \mathrm{nM}$, respectively.

Control (without any added Fe and other trace metals), [Control (second)] culture medium $(\leq 3 \mathrm{nM} \mathrm{Fe}$ ) was prepared to compare the growth rates and cell yields with those containing Fe and other trace metals. The light, temperature and nutrient conditions were the same as those of the stock culture described above. During the experiments, cell growth was monitored daily by triplicate cell counts (cells and not chains) using an optical microscope. Culture experiments were conducted in triplicate.

\section{RESULTS}

\section{Growth rate and maximall cell yields}

\section{Continuous cultivations by only addition of both Fe and macronutrients}

In the present study, the Direct-Fe ${ }^{\mathrm{III}}$ (first) medium induced the highest growth rate $(\mu=0.90-0.94$ / day) and the highest maximal cell yields (157 000 169000 cells $/ \mathrm{mL}$ ), showing values similar to those in the $\mathrm{f} / 2$ metal medium [Table 1 (1), Fig. 1]. In the continuous culture experiments by an inoculation of pre-culture and then addition of Fe into the control culture medium containing nutrient, however, the growth rates and maximal cell yields in the Direct-Fe ${ }^{\mathrm{III}}$ (second) and Direct-Fe ${ }^{\mathrm{III}}$ (third) media were approximately one-half and one-sixth to one-fourth, respectively, of those in the $\mathrm{f} / 2$ metal and Direct-Fe ${ }^{\mathrm{III}}$ (first) media. The relative order for the growth rates and maximal cell yields in the continuous culture experiments was $\mathrm{f} / 2$ metal $\approx$ Direct-Fe(Fe ${ }^{\mathrm{III}}$ (first) $\gg$ Direct-Fe $^{\mathrm{III}}$ (second) $\approx \operatorname{Direct}-\mathrm{Fe}\left(\mathrm{Fe}^{\mathrm{III}}\right.$ (third) $>$ Control (sectond) [Table 1 (1), Fig. 1].

\section{Effect of other trace metals in second culture media}

In the Direct-Metal (second) media for trace metals without any added $\mathrm{Fe}$, a little growth of T. weissflogii was observed with the growth rates of $0.6-0.7 /$ day and the maximal cell yields of 33 000-38 000 cells/mL for Mn and 21 000-24 000 cells $/ \mathrm{mL}$ for $\mathrm{Co}, \mathrm{Ni}, \mathrm{Cu}$ and $\mathrm{Zn}$ [Table 1 (2a), Fig. 2a].

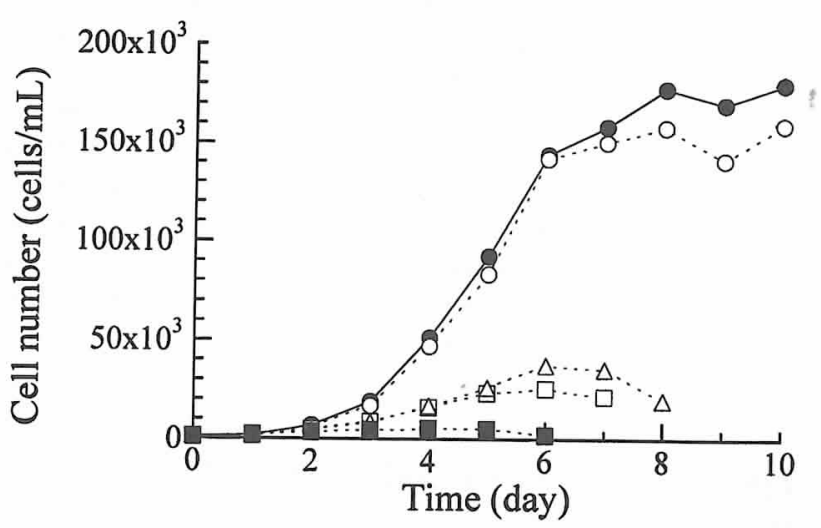

Fig. 1 Change in cell numbers of cultures supplied with f/2 metal (O) and with/without the addition of Fe by the continuous cultivations in the Direct-Fe ${ }^{\mathrm{III}}$ [first $(\mathrm{O})$, second $(\square)$ and third $(\triangle)]$ media and control culture medium without any added Fe $(\square)$. 
(a)

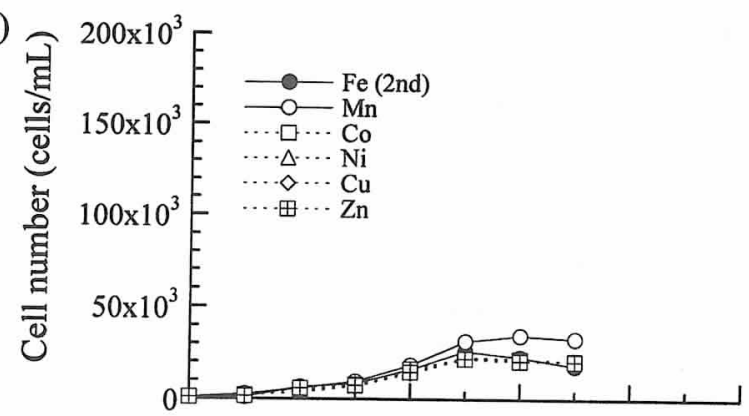

(b)

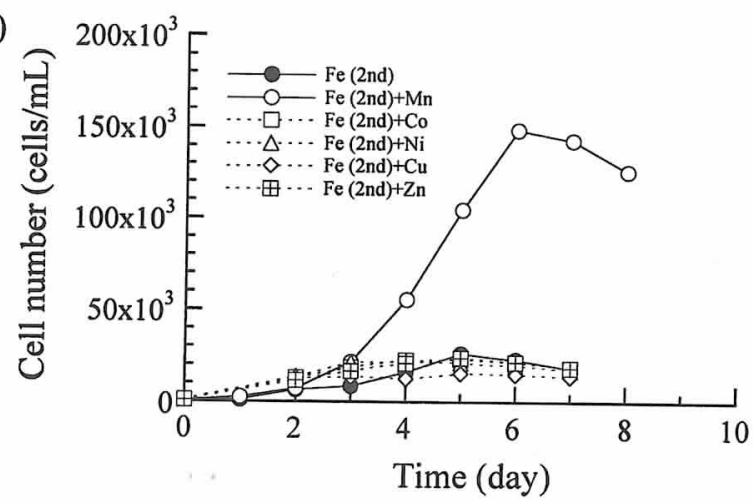

Fig. 2 Changes in cell numbers of cultures supplied with (a) each trace metal ( $\left.\mathrm{Fe}^{\mathrm{III}}, \mathrm{Mn}^{\mathrm{II}}, \mathrm{Co}^{\mathrm{II}}, \mathrm{Ni}^{\mathrm{II}}, \mathrm{Cu}^{\mathrm{II}}, \mathrm{Zn}^{\mathrm{II}}\right)$ in the control culture media without any added $\mathrm{Fe}$ in the Direct-Metal (second) media and (b) each trace metal $\left(\mathrm{Mn}^{\mathrm{II}}, \mathrm{Co}^{\mathrm{II}}, \mathrm{Ni}^{\mathrm{II}}, \mathrm{Cu}^{\mathrm{II}}, \mathrm{Zn}^{\mathrm{II}}\right)$ in the Direct-Fe ${ }^{\mathrm{III}}$ (second) media with $\mathrm{Fe}$ in the Direct-Fe $\mathrm{F}^{\mathrm{III}}+$ Metal (second) media.

Among the Direct-Fe + Metal (second) media, only Direct-Fe + Metal (second) media with the addition of both Fe and Mn induced the highest growth rate $(\mu=0.92-0.94 /$ day $)$ and the highest maximal cell yields ( $140000-163000$ cells $/ \mathrm{mL}$ ), almost the same as those obtained in the DirectFe $^{\text {III }}$ (first) medium [Table 1 (2b), Fig. 2b]. The growth rates $(\mu \approx 0.6 /$ day) and the maximal cell yields (21 000-25 000 cells $/ \mathrm{mL})$ in the Direct$\mathrm{Fe}+$ Metal (second)]media for Co, $\mathrm{Ni}$ and $\mathrm{Zn}$ were extremely low, similar to those in the Direct-Metal (second) media without any added Fe, while those in the Direct-Fe $+\mathrm{Cu}$ (second) medium for $\mathrm{Cu}$ were a little lower than those in the Direct-Fe + Metal (second) media for $\mathrm{Co}, \mathrm{Ni}$ and $\mathrm{Zn}$. The relative order for growth rates and maximal cell yields was Direct-Fe $+\mathrm{Mn}$ (second) $\gg$ Direct-Fe + Co $($ second $) \approx$ Direct-Fe $+\mathrm{Ni} \quad($ second $) \approx$ Direct-Fe $+\mathrm{Zn}$ (second) $>$ Direct-Fe $+\mathrm{Cu}$ (second)] media [Table 1 (2b), Fig. 2b].

\section{Continuous cultivations with addition of $\mathrm{Fe}, \mathrm{Mn}$ and macronutrients}

All continuous culture experiments in the Direct$\mathrm{Fe}+\mathrm{Mn}$ (first, second, third and fifth) media with (a)

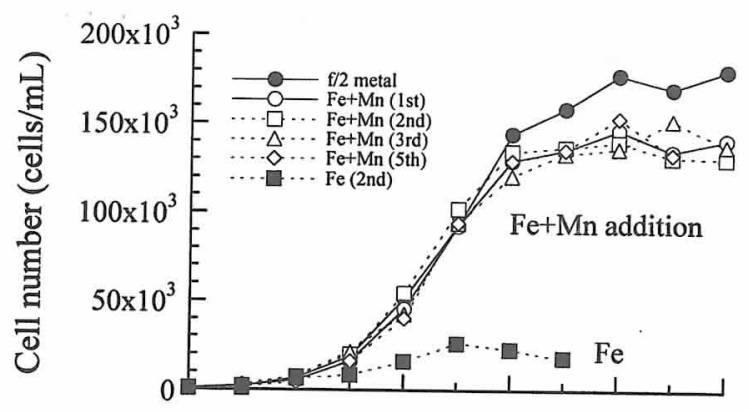

(b)

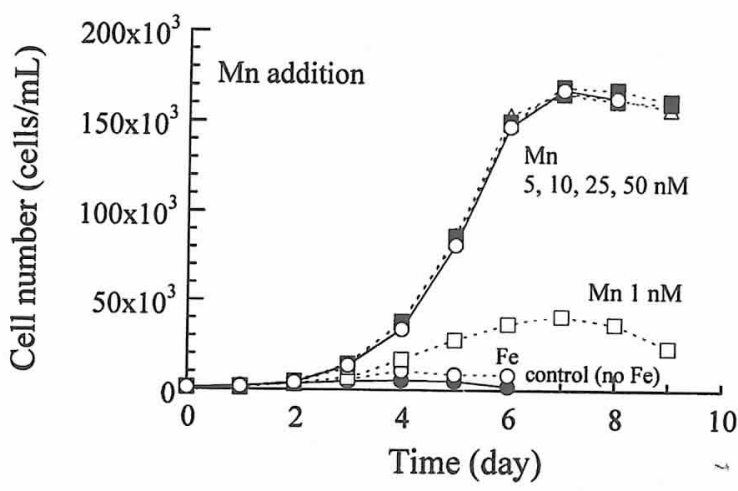

Fig. 3 Changes in cell numbers of cultures by the continuous culture experiments in (a) the Direct-Fe $+\mathrm{Mn}$ (first, second, third and fifth) media with $100 \mathrm{nM} \mathrm{Fe}$ and $25 \mathrm{nM} \mathrm{Mn}$ and (b) the Direct-Fe + Mn (second) media with different concentrations of $1,5,10,25$ and $50 \mathrm{nM}$ Mn.

$100 \mathrm{nM}$ Fe and $25 \mathrm{nM}$ Mn, which were prepared by an inoculation of pre-culture and the addition of both $\mathrm{Fe}^{\mathrm{III}}$ and $\mathrm{Mn}^{\mathrm{II}}$ to the control culture medium, induced almost the same maximum growth rate and maximal cell yield at the ranges of $0.90-1.0$ / day and $132000-163000$ cells $/ \mathrm{mL}$, respectively [Table 1 (3a), Fig. 3a].

Among the Direct-Fe $+\mathrm{Mn}$ (second) media with different $\mathrm{Mn}$ concentrations, the Mn concentrations of 5, 10, 25 and $50 \mathrm{nM}$ promoted nearly the same maximum growth rates ( $\mu=0.88-0.94 /$ day) and maximal cell yields (164000-171 000 cells/ $\mathrm{mL}$ ) as those in all continuous culture experiments in the Direct-Fe $+\mathrm{Mn}$ (first, second, third and fifth) media, while those in the Direct-Fe $+\mathrm{Mn}$ (second) medium with $1 \mathrm{nM} \mathrm{Mn}$ concentration and in the Direct-Fe ${ }^{\mathrm{III}}$ (second) medium without any added $\mathrm{Mn}$ were remarkably lower than those with $\mathrm{Mn}$ concentrations $\geq 5 \mathrm{nM}$. The order of growth rates and maximal cell yields was Direct-Fe+Mn (second) media with 5, 10, 25 and $50 \mathrm{nM}$ $\mathrm{Mn}>$ Direct-Fe + Mn (second) medium with $1 \mathrm{nM} \mathrm{Mn}>$ Direct-Fe $\mathrm{F}^{\mathrm{III}}$ (second) medium without any added $\mathrm{Mn} \geq$ Control medium without any added Fe and Mn [Table 1 (3b), Fig. 3b]. 


\section{Effect of Mn and/or Fe addition with different timing}

In direct $\mathrm{Mn}$ input and $\mathrm{Fe}+\mathrm{Mn}$ input to the Direct$\mathrm{Fe}^{\mathrm{III}}$ (second) medium [Table 1 (4a), Fig. 4a], the growth rates and maximal cell yields decreased rapidly with incubation time (0-8 days) in the Direct-Fe ${ }^{\mathrm{III}}$ (second) medium although the maximum cell density (140 000-171 000 cells/mL) by $\mathrm{Mn}$ input after four days incubation in the Direct-Fe ${ }^{\mathrm{III}}$ (second) medium was the same as that after 0 days incubation. Only $\mathrm{Mn}$ and both Fe $+\mathrm{Mn}$ inputs after 8 days incubation induced only a little increase in the cell density (Fig. 4a).

In direct Fe input to the Direct-Mn (second) medium [Table 1 (4b), Fig. 4b], the maximal cell yields were high $(\sim 150000$ cells $/ \mathrm{mL}$, almost the same in all media) and independent of incubation time (0-8 d) in the present study. The growth rates by $\mathrm{Fe}$ input after 2-8 days incubations were almost the same in all media with one-half to one-third lower values than that after 0 days incubation.

(a)

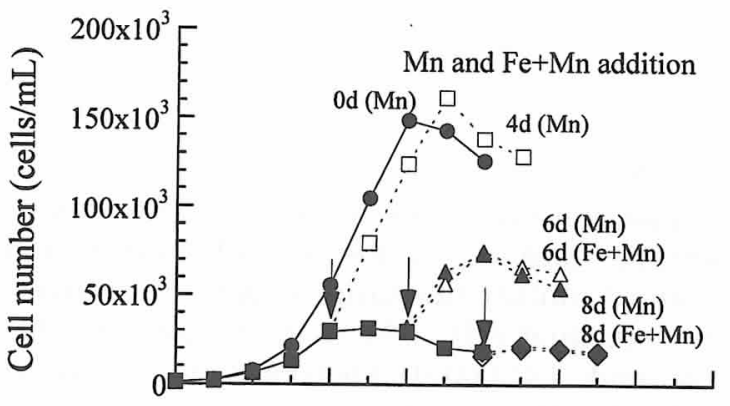

(b)

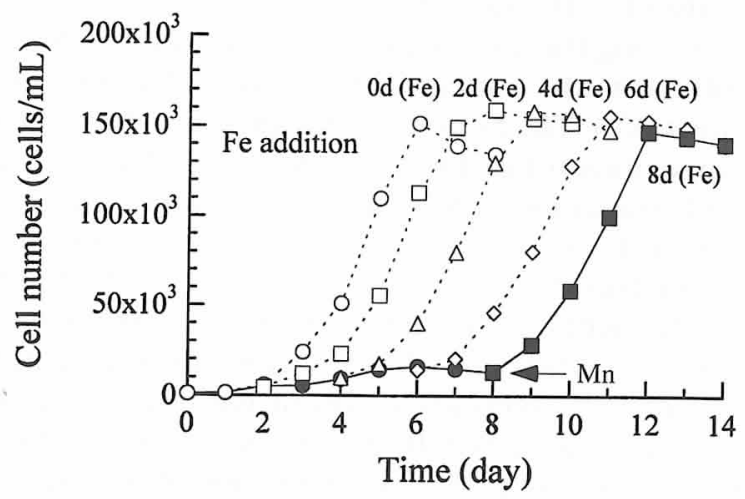

Fig. 4 Changes in cell numbers of cultures by (a) addition of $\mathrm{Mn}$ or $\mathrm{Fe}+\mathrm{Mn}$ with different timing during incubation for several days in the Direct-Fe ${ }^{\text {III }}$ (second) media and (b) addition of $\mathrm{Fe}$ with different timing during incubation for several days in the Direct-Mn (second) media.

\section{DISCUSSION}

\section{Significance of Mn and Fe for growth of coastal marine diatoms}

Trace metals influence phytoplankton production and community structure. These biological influences are particularly important for several metals of the first transition series which are required by phytoplankton for various metabolic functions: $\mathrm{Mn}, \mathrm{Fe}, \mathrm{Co}, \mathrm{Ni}, \mathrm{Cu}$ and $\mathrm{Zn}$. Fe is the most important of all the bioactive trace metals as an important component of such biochemical processes as photosynthetic and respiratory electron transport, nitrate and nitrite reduction, and other biochemical reactions. ${ }^{1}$ However, sufficient growth of a coastal diatom $T$. weissflogii was not observed in the continuous second and third culture experiments by an inoculation of pre-culture to the control medium, to which only Fe and macronutrients were added (Fig. 1). However, the addition of both $\mathrm{Mn}$ and $\mathrm{Fe}$ in the culture experiments (Fig. 2b) induced the highest growth rates $(\mu=0.92-0.94 /$ day $)$ and maximal cell yields of T. weissflogii [Table 1 (2)]. Moreover, the highest growth was maintained in the continuous first, second, third, fourth (data not shown) and fifth media to which both $\mathrm{Mn}$ and Fe were added (Fig. 3a). Conversely, the addition of both $\mathrm{Cu}$ and Fe to the culture medium had a negative effect on phytoplankton growth probably because of $\mathrm{Cu}$ toxicity at high concentration of $25 \mathrm{nM}$ in the present study.

The observed concentrations for dissolved Mn in open ocean surface waters are normally between 0.1 and $3 \mathrm{nM},{ }^{8,9,12}$ resulting from atmospheric inputs to the oceans. However, the main sources of $\mathrm{Mn}$ to coastal waters are generally from river runoff and a dissolved Mn flux from shelf sediments. It has been reported that dissolved Mn in the coastal surface waters reached approximately $10-25 \mathrm{nM}$ during the coastal upwelling conditions over the shelf. ${ }^{23}$ These observed concentrations of dissolved $\mathrm{Mn}$ in surface waters are much higher than the equilibrium concentration $(<<1 \mathrm{nM})$ of dissolved $\mathrm{Mn}$ with solid $\mathrm{MnO}_{2}$ or $\mathrm{MnOOH}$ in oxygenated sea water and are partially maintained by the relatively slow oxidation kinetics of $\mathrm{Mn}^{2+} \cdot 8,11,24$ In the present culture experiments, the filtered coastal water was autoclaved for $20 \mathrm{~min}$ at $121^{\circ} \mathrm{C}$ to prepare the culture medium. The autoclaving treatment $\left(121^{\circ} \mathrm{C}\right)$ probably promoted the formation of solid $\mathrm{MnO}_{2}$ or $\mathrm{MnOOH}$ with low solubility by hastening the oxidation rate of dissolved $\mathrm{Mn}^{2+}$ and then changing to larger and more stable solid $\mathrm{MnO}_{2}$ or $\mathrm{MnOOH}$ phases, resulting in the decrease in bioavailable dissolved $\mathrm{Mn}$ concentration in the 
medium (data not shown). In a previous study, ${ }^{25}$ the autoclaving treatment of the freshly precipitated amorphous $\mathrm{Fe}^{\mathrm{III}}$ hydroxide (am-Fe $\mathrm{Fe}^{\mathrm{III}}$ ) in sea water accelerated the conversion to a more stable solid am-Fe ${ }^{\mathrm{III}}$ phase by loss of water and increased crystallization. The conversion to a stable am-Fe $\mathrm{IIII}^{\mathrm{III}}$ phase with low solubility and dissolution rate greatly decreased iron availability of phytoplankton. ${ }^{25,26}$ In the present study, high growth of T. weissflogii was observed in the nutrient enrichment culture experiments (except for the first culture media with only Fe addition, Fig. 1) with only the addition of both $\mathrm{Mn}$ and Fe (Table 1). Manganese $(\geq 5 \mathrm{nM})$ and $\mathrm{Fe}(\geq 100 \mathrm{nM})^{21}$ in the direct metal input media were both required to support the sufficient growth (maximum cell yields) of $T$. weissflogii. Therefore, it may be suggested that dissolved $\mathrm{Mn}$ and Fe in coastal waters are reduced to extremely low levels (low bioavailable $\mathrm{Mn}$ and $\mathrm{Fe}$ ) by autoclaving although other dissolved trace metals such as $\mathrm{Co}^{\mathrm{II}}, \mathrm{Ni}^{\mathrm{II}}, \mathrm{Cu}^{\mathrm{II}}$ and $\mathrm{Zn}^{\mathrm{II}}$ are probably not influenced.

Among the Direct-Fe + Mn (second) media with different $\mathrm{Mn}$ concentrations (1-50 nM), the media with $\mathrm{Mn}$ concentrations $\geq 5 \mathrm{nM}$ promoted nearly the same maximum growth rate and maximal cell yield of $T$. weissflogii while the growth in the media with $1 \mathrm{nM} \mathrm{Mn}$ concentration and without any added Mn was remarkably low (Fig. 3b). It has been reported that the reproductive rate of oceanic diatom Thalassiosira oceanica was limited at $\mathrm{Mn}$ activities below $10^{-10} \mathrm{M}(0.1 \mathrm{nM})$ using EDTA-trace metal ion buffer systems while that of neritic diatom Thalassiosira pseudonana estuarine isolate was limited below $10^{-9} \mathrm{M}(1 \mathrm{nM}){ }^{13,27}$ The lowest free manganese ion concentration for the growth of T. pseudonana was nearly consistent with the

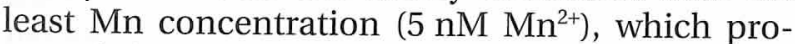
moted the maximal growth rate and cell yield of T. weissflogii in the present study. In addition, Brand et al. ${ }^{13}$ reported that there is a clear distinction between neritic and oceanic phytoplankton for Fe. All of the neritic phytoplankton had substantially decreased reproductive rates below $10^{-7}$ $\mathrm{M}$ Fe while the oceanic phytoplankton were either not or only slightly limited at the lowest Fe concentrations $\left(\sim 10^{-9} \mathrm{M}\right)$. Recently, it has been reported that the oceanic diatom had up to several-fold lower photosystem I (PS I) and lower cytochrome $b_{6} f$ complex concentrations than a coastal diatom and these changes to the photosynthetic apparatus markedly decrease the cellular Fe requirements of the oceanic diatom but not its photosynthetic rates. ${ }^{28,29}$ In the present study, $\mathrm{Mn}(\geq 5 \mathrm{nM})$ and Fe $(\geq 100 \mathrm{nM})$ in the direct metal input media without any other trace metals were both required to support sufficient growth of T. weissflogii in con- tinuous culture experiments with sufficient macronutrients. In addition, it may be suggested that other trace metals (Co, Ni, $\mathrm{Cu}$ and $\mathrm{Zn}$ ) except for $\mathrm{Mn}$ and $\mathrm{Fe}$ are present at levels sufficient to support the high growth for coastal diatoms in the control media, which were produced from natural coastal waters in the present study.

\section{Full growth recovery in Mn-sufficient waters}

Manganese is an essential micronutrient required for oxidation of water in photosynthesis and for detoxification of superoxide radicals. ${ }^{5}$ In photosynthetic reactions, manganese is used to produce molecular oxygen, protons and electrons from water by a Mn-based enzyme system in a photosystem II (PS II). ${ }^{30}$ It is now known that each Mn in the four-Mn cluster each loses an electron to PS II, with replacement of these electrons from the oxidation of two water molecules to molecular oxygen. This photosynthetic pathway couples the generation of an excited state on chlorophylmolecules for electron transport. In addition to ferredoxins (iron-sulfur proteins), redox-active molecules such as quinones, blue copper proteins and cytochromes (iron hemoproteins) can also be involved in the electron transfer chain throughout the photosystems (PS I and PS II). In addition, Mn also appears to be used in the antioxidant enzyme superoxide dismutase (SOD) to detoxify the reactive oxygen species (ROS) such as superoxide, hydroxyl radical, hydrogen peroxide and organohydroperoxide, which are a by-products of normal cellular metabolism and are commonly generated under conditions of metal overload by metal redox reactions. ${ }^{31}$ Of the four known SOD isoforms, distinguished by their metal cofactors ( $\mathrm{Fe}, \mathrm{Mn}, \mathrm{Cu} / \mathrm{Zn}$ and $\mathrm{Ni}$ ), Mn-SOD is the dominant form in the diatom Thalassiosira pseudonana and chloroplastic Mn-SOD accounts for $10-20 \%$ of cellular Mn, depending on incident light intensity and cellular growth rate. ${ }^{32}$

In the present study, direct $\mathrm{Mn}$ and $\mathrm{Mn}+\mathrm{Fe}$ inputs after 6-8 days incubation in Fe-sufficient medium without any added $\mathrm{Mn}$ in the Direct-Fe $\mathrm{e}^{\mathrm{III}}$ (second) medium showed only a small effect on the growth of T. weissflogii (Fig. 4a) while direct Fe input after 0-8 days incubation in Mn-sufficient medium without any added Fe in the Direct-Mn (second) medium promoted growih with full recovery (Fig. 4b). The sufficient growth by direct Fe input even after 6-8 days incubation probably results from maintaining the high physiological recovery activity of a cell for a long incubation period in Fe-deficient and Mn-sufficient media. It has been reported that coastal and oceanic 
diatoms require more $\mathrm{Mn}$ to grow in Fe-deficient than in Fe-sufficient sea water. ${ }^{33}$ Fe-limitation of diatom growth increases the rate of production of ROS, and the corresponding up-regulation of the superoxide dismuting enzyme Mn-SOD increases the requirement for $\mathrm{Mn}$. According to Peers and Price, ${ }^{33}$ SOD enzyme activity increased in Fedeficient T. weissflogii compared with Fe-replete cells and the Mn content of the SODs of T. weissflogii increased in Fe-limited cells. Therefore, T. weissflogii in Fe-deficient and Mn-sufficient media such as the Direct-Mn (second) medium in the present study could retain the ability for full physiological recovery for several days, probably by decreasing the oxidative stress of phytoplankton with high rates of consumption of ROS. However, Mn-limited T. weissflogii in the Fe-sufficient medium could not recover full physiological activity probably by simultaneously increasing the rates of production of ROS. Chrichton ${ }^{31}$ reported that excess Fe accumulated by the cells could participate in oxygen radical generation. According to our laboratory results, the addition of only $\mathrm{Mn}$ and $\mathrm{Fe}$ allows for the full recovery of photosynthesis and the detoxification of superoxide, allowing maximal growth. Fe enrichments stimulated phytoplankton growth without losing the ability for full physiological recovery in Fe-deficient and Mn-sufficient waters. Therefore, Mn may play an important role in maintaining the ability for full physiological recovery for a long time in low Fe regions of the ocean. Future work will aim to measure the activity level of ROS and SOD in Mn-deficient and Fe-sufficient media and Mn-sufficient and Fe-deficient media.

\section{ACIKNOWLEDGMENT}

This study was partially supported by grants for Scientific Research (Nos 17651001 and 18201001) from the Ministry of Education, Culture, Sports, Science and Technology, Japan.

\section{REFERENCES}

1. Weinberg ED. Cellular regulation of iron assimilation. $Q$. Rev. Biol. 1989; 64: 261-290.

2. Geider RJ, Roche JL. The role of iron in phytoplankton photosynthesis, and the potential for iron-limitation of primary productivity in the sea. Photosynth. Res. 1994; 39: 275-301.

3. Stumm W, Morgan JJ. Aquatic Chemistry, 3rd edn. WileyInterscience, New York, NY. 1996.

4. Waite TD. Thermodynamics of the iron system in seawater. In: Turner DR, Hunter KA (eds). The Biogeochemistry of Iron in Seawater. Wiley, New York, NY. 2001; 291-342.
5. Burnell JN. The biochemistry of manganese in plants. In: Graham RG, Hannam RJ, Uren NC (eds). Manganese in Soils and Plants. Klewer, New York, NY. 1988; 125-137.

6. Jones CJ, Murray JW. The geochemistry of manganese in the northeast Pacific Ocean off Washington. Limnol. Oceanogr. 1985; 30: 81-92.

7. Landing WM, Bruland KW. The contrasting biogeochemistry of iron and manganese in the Pacific Ocean. Geochim. Cosmochim. Acta 1987; 51: 29-43.

8. Bruland KW, Donat JR, Hutchins DA. Interactive influences of bioactive trace metals on biological production in oceanic waters. Limnol. Oceanogr. 1991; 36: 1555-1577.

9. Nakayama E, Obata H, Okamura K, Isshiki K, Karatani H, Kimoto T. Iron and manganese in the atmosphere and oceanic waters. In: Sakai H, Nozaki Y (eds). Biogeochemical Processes and Ocean Flux in the Western Pacific. Terra Scientific Publishing, Tokyo. 1995; 53-68.

10. Sunda WG, Huntsman SA. Effect of sunlight on redox cycles of manganese in the southwestern Sargasso Sea. Deep-Sea Res. 1988; 35: 1297-1317.

11. Gramm-Osipov LM. Formation of solid phases of manganese in oxygenated aquatic environments. In: Nicholson $\mathrm{K}$, Hein JR, Buhn B, Dasgupta S (eds). Manganese Mineralization: Geochemistry and Mineralogy of Terrestrial and Marine Deposit. Geological Society Special Publication No. 119. Geological Society of America, Bath. 1997; 301-308.

12. Jickells T, Church T, Veron A, Arimoto R. Atmospheric inputs of manganese and aluminium to the Sargasso Sea and their relation to surface water concentrations. Mar. Chem. 1994; 46: 283-292.

13. Brand LE, Sunda WG, Guillard RRL. Limitation of marine phytoplankton reproductive rates by zinc, manganese and iron. Limnol. Oceanogr. 1983; 28: 1182-1198.

14. Coale KH. Effects of iron, manganese, copper, and zinc enrichments on productivity and biomass in the subarctic Pacific. Limnol. Oceanogr. 1991; 36: 1851-1864.

15. Obata H, Karatani H, Nakayama E. Automated determination of iron in seawater by chelating resin concentration and chemiluminescence detection. Anal. Chem. 1993; 65: 1524-1528.

16. Obata H, Karatani H, Matsui M, Nakayama E. Fundamental studies for chemical speciation of iron in seawater with an improved analytical methods. Mar. Chem. 1997; 56: 97106.

17. Guillard RRL, Ryther JH. Studies of marine planktonic diatoms. I. Cyclotella nana Hustedt and Detonula confervacea (Gleve) Gran. Can. J. Microbiol. 1962; 8: 229-239.

18. Morel FMM, Rueter JG, Anderson DM, Guillard RRL. Aquil: a chemistry defined phytoplankton culture medium for trace metal studies. J. Phycol. 1979; 15: 135-141.

19. Kuma K, Tanaka J, Matsunaga K. Effect of natural and synthetic organic-Fe(III) complexes in an estuarine mixing model on iron uptake and growth of a coastal marine diatom, Chaetoceros sociale. Mar. Biol. 1999; 134: 761-769.

20. Kuma K, Tanaka J, Matsunaga K, Matsunaga K. Effect of hydroxamate ferrisiderophore complex (ferrichrome) on iron uptake and growth of a coastal marine diatom, Chaetoceros sociale. Limnol. Oceanogr. 2000; 45: 1235-1244.

21. Yoshida M, Kuma K, Iwade S, Isoda Y, Takata H, Yamada M. Effect of aging time on the availability of freshly precipitated ferric hydroxide to coastal marine diatoms. Mar. Biol. 2006; 149: 379-392. 
22. Iwade S, Kuma K, Isoda Y, Yoshida M, Kudo I, Nishioka J, Suzuki K. Effect of high iron concentrations on iron uptake and growth of a coastal diatom Chaetoceros sociale. Aquat. Microb. Ecol. 2006; 43: 177-191.

23. Chase Z, Johnson KS, Elrod VA, Plant JN, Fitzwater SE, Pickell L, Sakamoto CM. Manganese and iron distributions off central California influenced by upwelling and shelf width. Mar. Chem. 2005; 95: 235-254.

24. Murray JW, Dillard JG, Giovanoli R, Moers H, Stumm W. Oxidation of $\mathrm{Mn}(\mathrm{II})$ : initial mineralogy, oxidation state and ageing. Geochim. Cosmochim. Acta 1985; 49: 463-470.

25. Kuma K, Matsunaga K. Availability of colloidal ferric oxides to coastal marine phytoplankton. Mar. Biol. 1995; 122: 1-11.

26. Wells ML, Zorkin NG, Lewis AG. The role of colloid chemistry in providing a source of iron to phytoplankton. J. Mar. Res. 1983; 41: 731-746.

27. Sunda WG, Huntsman SA. Relationships among growth rate, cellular manganese concentrations and manganese transport kinetics in estuarine and oceanic species of the diatom Thalassiosira. J. Phycol. 1986; 22: 259-270.
28. Strzepek RF, Harrison PJ. Photosynthetic architecture differs in coastal and oceanic diatoms. Nature 2004; 431: 689-692.

29. Peers G, Price NM. Copper-containing plastocyanin used for electron transport by an oceanic diatom. Nature 2006; 441: 341-344.

30. Frausto da Silva JJR, Williams RJP. The Biological Chemistry of the Elements: The Inorganic Chemistry of Life, 2nd edn. Oxford University Press, New York, NY. 2001.

31. Chrichton RR. Inorganic Biochemistry of Iron Metabolism: From Molecular Mechanisms to Clinical Consequences, 2nd edn. Wiley, New York, NY. 2001.

32. Wolfe-Simon F, Starovoytov V, Reinfelder JR, Schofield O, Falkowski PG. Localization and role of manganese superoxide dismutase in a marine diatom. Plant Physiol. 2006; 142: 1701-1709.

33. Peers G, Price NM. A role for manganese in superoxide dismutases and growth of iron-deficient diatoms. Limnol. Oceanogr. 2004; 49: 1774-1783. 